\title{
STRENGTHENING EPP (ENGLISH PROFICIENCY PROGRAM) PROGRAM IN IMPROVING ENGLISH ABILITY OF MUHAMMADIYAH 2 TAMAN STUDENTS
}

Fitrijah Hidajati ${ }^{1}$ and Miftahol Jannah ${ }^{2}$

${ }^{1}$ Universitas Muhammadiyah Sidoarjo, Sidoarjo, fitrijahhidajati@gmail.com

${ }^{2}$ Universitas Muhammadiyah Sidoarjo, Sidoarjo, miftahjannahfirdaus@gmail.com

\begin{abstract}
This paper discusses the importance of Strengthening the EPP (English Proficiency Program) Program in Improving Students' English Language Ability in Muhammadiyah 2 Middle School, Taman In this 21st century era, the literacy ability of students is closely related to the demands of reading skills that lead to the ability to understand information analytically, critically, and reflectively. The rapid development of technology has changed the landscape of education globally especially in facing the challenges of the industrial revolution 4.0 and preparing graduates (outputs) who will live in an era that will integrate technology thoroughly even blurring physical, digital and life boundaries biologically and is predicted to have a profound influence very big on the work environment, social and even culture that exists. This research is a qualitative-descriptive research which is expected to be able to uncover various information with a careful and meaningful description-analysis. Data sources in this study include the principal, vice principal of curriculum affairs, English language teacher. Data collection is done by interview, observation, and documentation. As for the data analysis technique through the stages of data reduction, data presentation and data analysis. The results of this research are (a) School based management program can be implemented by strengthening the EPP (English Proficiency Program) program (b) Strengthening the EPP (English Proficiency Program) program able to improve English language skills.
\end{abstract}

Keywords: EPP Program, English Subject, Language Ability

Abstrak. Artikel ini membahas tentang pentingnya Memperkuat Program EPP (Program Kemahiran Bahasa Inggris) dalam Meningkatkan Kemampuan Bahasa Inggris Siswa di Sekolah Menengah Muhammadiyah 2, Taman. Pada abad ke-21 ini, kemampuan membaca siswa berkaitan erat dengan tuntutan keterampilan membaca yang mengarah pada kemampuan untuk memahami informasi secara analitis, kritis, dan reflektif. Pesatnya perkembangan teknologi telah mengubah lanskap pendidikan secara global terutama dalam menghadapi tantangan revolusi industri 4.0 dan mempersiapkan lulusan yang akan hidup di era yang akan mengintegrasikan teknologi secara menyeluruh bahkan mengaburkan batas fisik, digital dan batas kehidupan secara biologis dan diprediksi memiliki pengaruh mendalam yang sangat besar pada lingkungan kerja, sosial bahkan budaya yang ada. Penelitian ini adalah penelitian kualitatif-deskriptif yang diharapkan dapat mengungkap berbagai informasi dengan analisis uraian yang cermat dan bermakna. Sumber data dalam penelitian ini meliputi kepala 
sekolah, wakil kepala sekolah urusan kurikulum, guru bahasa Inggris. Pengumpulan data dilakukan dengan wawancara, observasi, dan dokumentasi. Adapun teknik analisis data melalui tahapan reduksi data, penyajian data dan analisis data. Hasil dari penelitian ini adalah (a) Program manajemen berbasis sekolah dapat diimplementasikan dengan memperkuat program EPP (Program Kecakapan Bahasa Inggris) (b) Memperkuat program EPP (Program Kecakapan Bahasa Inggris) yang mampu meningkatkan keterampilan berbahasa Inggris.

Kata Kunci: EPP Program, Pembalajaran Bahasa Inggris, Kemampuan Berbahasa

\section{Introduction}

The effect of globalization on various fields of human life requires innovation and efforts to continuously improve quality in various ways including improving the quality of human resources. In connection with these problems it is necessary to improve the ability to communicate in English in order to enter and compete at the international level. English language skills are a must in the era of communication and globalization

The era of the industrial revolution which is currently taking place very quickly requires the younger generation to always develop their own potential that can benefit for their future. One thing that needs to be mastered to improve competitiveness in the global market is the mastery of English. English as an international language plays a very important role in the world of industry, trade and education. Almost all sectors use English as the language of instruction. Seeing its dominant role, it is fitting that the mastery of English language skills becomes an important part for students in Indonesia

Technology disruption has made significant changes in changing the face and order of higher education not only in Indonesia but also throughout the world. The presence of a variety of expertise and new literacy needed by the industry sector now makes higher education must adjust to the climate or industry trends and increasingly competitive business. The application of online technology in various industrial sectors that prioritizes high speed and accuracy makes universities inevitably have to formulate and adjust curriculum in harmony with these changes. However, the need for mastering soft skills (human literacy) that are qualified in sustaining data literacy skills and technology must still be prioritized

All related stakeholders are expected to be able to face the challenges of the industrial revolution 4.0 era wisely. Despite the demand to continue to innovate and 
conduct research that can sustain the economy that has a direct impact on the welfare of society and the nation's competitiveness in the arena of global competition, the strengthening of the application of the values of Pancasila and religion which are the basic foundations of national and state life, must continue to be maintained in anticipation of not only disruption of technology but also civilization

The EPP (English Proficiency Program) program is one of the school-based policies. School Based Management (SBM) is an education system where there is a decentralized authority and responsibility for making decisions related to the allocation of resources within an integrated framework (centrally determined framework) that is influenced by objectives, policies, standards and accountability. Sources here are broadly defined which include technological knowledge, power, material, personnel, time, results of studies, information and funds. According to Dede Rosyada School-based management (School Based Management) is a formal process that involves principals, teachers, students' parents, students and the community who are close to the school, in the process of making various decisions. Management steps are essentially problem solving processes, so management steps are not as different as problem solving steps, namely: problem identification, problem diagnosis, goal setting, decision making, planning, organizing, coordinating, delegating, communicating, working with groups and assessments. While management activities include: Planning (planning), Organizing (organizing), Mobilization (leading), and Supervision (controlling). For success in achieving a goal requires a professional dream, where he understands his duties and obligations as a leader, as well as carrying out his role as a leader. In addition, the leader must establish a good cooperative relationship with subordinates, so as to create a working atmosphere that makes subordinates feel safe, peaceful, and have a freedom in developing their ideas in order to achieve the common goals that have been set.

\section{Research Methodology}

This research is a field research because it is carried out in real terms and based on facts in the field. ${ }^{1}$ This type of research is descriptive-qualitative research. The informants in this study were the principal, vice principal of school curriculum and English teacher at Muhammadiayh 2 Taman Middle School.

${ }^{1}$ Sugiyono, Metode Penelitian Pendidikan, Pendekatan Kuantitatif, Kualitatif dan RandD. (Bandung: Alfabeta, 2011) 
Data collection is done by observation, interviews and documentation which are then analyzed by descriptive-analysis using the inductive method. Observation was carried out since pre-research and throughout the research process which was assisted by a field note and observation checklist to determine environmental conditions and activities carried out in expressing the process of strengthening the EPP (English Proficiency Program) program in improving students' English proficiency. The interview process is carried out by way of face-to-face meeting between the researcher and the informant. Documentation was carried out to obtain policy data in the form of draft concepts for strengthening the EPP (English Proficiency Program) curriculum and the documentation of student achievement.

\section{Discussion and Research Results}

School-Based Management Perspectives

In developing new programs in schools, the principal always carries out a process of influence in setting organizational goals, motivating followers' behavior to achieve goals, influencing to improve their groups and culture. It also influences the interpretation of the events of followers, organizing and activities to achieve goals, maintaining cooperative relations and group work, gaining support and cooperation and people outside the group or organization ${ }^{2}$. Leadership is an ability to mobilize, influence, motivate, invite, direct, advice, guide, order, order, prohibit and even punish and conduct coaching with the intention that humans as media management want to work in achieving administrative objectives effectively and efficiently. ${ }^{3}$

Meanwhile, leaders are defined as people who have the power to influence and inspire others so that they show certain responses in realizing the vision and mission of the organization. ${ }^{4}$ That the management of the program by the principal must provide all the parties involved in the school. From the two opinions above it can be concluded that the process of influencing in determining organizational goals, motivating followers' behavior to achieve goals, influencing to improve the group and culture so that humans as management media want to work in achieving administrative goals effectively and efficiently in carrying out program management in schools. Relation to leadership, the leader in conducting leadership

\footnotetext{
${ }^{2}$ Barnawi and M. Arifin, Kinerja Guru Profesional, (Jogjakarta: Ar-Ruzz Media, 2012) 67

${ }^{3}$ E. Mulyasa. Menjadi Kepala Sekolah Profesional, (Bandung: PT Remaja Rosdakarya, 2006), 108

${ }^{4}$ Iskandar A and Yufridawati, Pengembangan Pola Kerja Harmonis dan Sinergis Antara Guru, Kepala Sekolah dan Pengawas, (Jakarta: Bestari Buana Murni, 2013) 106
} 
practices, he behaves in such a way that is in accordance with his personality. As a result followers do what the leader wants in conditions of compliance that are not forced. That is, follower obedience takes place consciously. That is the true essence of ideal leadership harmonization ${ }^{5}$. Schools can be seen as an organization as well as an integrated education system that is related to the management function by assigning tasks into parts and allocating resources, spreading organizational resources to achieve strategic goals. The distribution of resources is reflected through the division of labor or specific jobs, formal lines of authority, and coordinating mechanisms for diverse organizational tasks.

In the school there are a number of education and non-education staff who have specific tasks. The principal is defined as "a functional teacher is given the task to lead a school where teaching and learning processes are held or where interaction occurs between the teacher giving the lesson and the student receiving the lesson". Principals are successful if they understand the existence of the school as a complex and unique organization, and are able to carry out the role of the principal as a person who is given the responsibility to lead the school. The success of the principal shows that the principal is a person who determines the center and rhythm of a school. In addition, it can be said that the success of the principal is success to the school.

Many studies show that the leadership style found in an organization is a factor related to organizational productivity and efficiency. Some determinants of work productivity include leadership climate. Hamper is the same as Mulyasa's opinion A similar matter was also expressed by Mulyasa; shows six factors that also determine the level of productivity, namely education, technology, values, work climate, health status, and the level of minimum wages. Of the six factors that support the productivity of the teaching workforce, explicitly mentioned in the work climate is outlined the importance of the principal's leadership. ${ }^{6}$ Thus the essential leadership function is reflected in the ability of a leader to be the direction maker, the representation and mouthpiece of the organization, the effective communicator, the mediator and the integrator.

The success of many school organizations is determined by the success of school principals in carrying out their roles and duties. The role is a set of attitudes

${ }^{5}$ Wahyosumidjo, Kepemimpinan Kepala Sekolah, (Jakarta: GrafindoPersada, 2002), 81-83

${ }^{6}$ Depdiknas. Kepemimpinan Kepala Sekolah Dalam Meningkatkan Sumber Daya Manusia Di Sekolah Dasar. ( Jakarta, 2007), 12 
and behaviors that must be carried out in accordance with its position in the organization. The role not only shows duties and rights, but also reflects the responsibility and authority in the organization. There are many theories of leadership style that can be applied by school principals. When examined from the development of theory, there are many theories of leadership that can be explored to examine the problem of leadership.

School based management is a term derived from three words namely: management, based, and school. Each has the first meaning, management is "the coordination and harmonization of resources through a number of management inputs to achieve goals or to meet customer needs, secondly, based is based on or focused on, third, schools are an organization that is lower in the ranks of the Ministry of National Education (MONE) tasked with providing 'basic skills' to students on the basis of legalistic (macro, meso, micro) and professionalism provisions. ${ }^{7}$

School-based management according to Rahmat and Edi Suharto is the delegation of decision-making authority to manage financial resources, curriculum, and professionalism of teachers at the school level. ${ }^{8}$ School-based management is "the coordination and matching of resources that are carried out automatically (independently) by schools through a number of management inputs to achieve school goals within the framework of national education, by involving all the interest groups associated with schools directly in the decision making process" In general, school-based quality improvement management can be interpreted as "coordinating and harmonizing resources that are carried out independently by the school by involving all interest groups associated with the school (stakeholders) directly in the decision making process to meet school quality needs or to achieve quality objectives school within the framework of national ${ }^{9}$ education policy ". In this management schools are given the flexibility to manage resources and funding sources by allocating them according to priority needs, and being more responsive to local needs.

Basic Concepts of School Based Management

The purpose of school-based management

${ }^{7}$ E. Mulyasa, Manajemen Berbasis Sekolah, (Bandung: Rosada Karya, 2002), 30

${ }^{8}$ Rahmat and Edi Suharto, Konsep Manajemen Berbasis Sekolah, (2001), 39

${ }^{9}$ Gatot and Martono.E. , Ilmudan Seni Kepemimpinan, (Bandung :Pustaka Reka Cipta, 2014), 95 
In general and overall the SBM aims to make schools able to be independent in all aspects of their education management so that schools can determine the direction of development in accordance with the conditions and objective needs of the community. Therefore the learning programs presented by schools must be relevant to the needs of the community so that the community can be involved, participate in, and support educational activities and processes within the school. A harmonious relationship between school and society is a relationship that must be continually fostered so that the products (outcomes) of education are no longer foreign to the community. ${ }^{10}$

\section{Characteristics of School-based Management}

School-based management has characteristics that must be understood by schools that will apply them to clarify the characteristics of SBM. Then the inputprocess-output system approach will be used. There are three aspects that matters in this concept; output, process, and educational input.

The first approach is output because output will be used the first approach is output because output has the highest level of importance. "Output is school performance. School performance is the achievement of schools resulting from the school process ".${ }^{11}$ The output is usually divided into two categories namely academic achievement and non academic achievement.

According to Umaedi in the second process, there are several categories that must be considered including the effectiveness of the teaching and learning process, strong school leadership, effective processing of education personnel, schools have quality culture, schools have compact, intelligent and dynamic team work, schools have authority (independence) and (transparency), school management has a willingness to change, schools conduct evaluations and improvements on an ongoing basis, schools are responsive and anticipatory to needs and schools have accountability and sustainability. ${ }^{12}$

Educational input is an equally important part of the process and output. Which are input indicators including the condition of the teacher (professionalism), the condition of students, adequate facilities and infrastructure

${ }^{10}$ Rahmat and Edi Suharto, Konsep Manajemen Berbasis Sekolah, 2001

${ }^{11}$ Taufiqurrahman, "Manajemen Berbasis Sekolah", Jurnal Studi Keislaman, 2002

${ }^{12}$ E. Mulyasa, Manajemen Berbasis Sekolah, (Bandung: Rosda Karya, 2002), 30 
According to Umaedi the important parts of the input include that the school must have a quality policy, available resources, high performance expectations, a focus on customers (especially students), management input. Characteristics of MBS are the first, cchool organization, including provides organizational management for transformative leadership in achieving school goals, develop a school plan and formulate policies for your own school, manage school operational activities, ensuring effective communication between the school and the related community (school community), and ensuring that schools will be held accountable (accountable to the community and government). The second, teaching and learning process, including, improve the quality of student learning, develop a curriculum that is suitable and responsive to the needs of students and the school community, carry out effective teaching, provide development programs that are needed by students, and development programs needed by students. The third, human resources, including, empower the nature and put a period that can serve the needs of all students, select staff who have insight into school-based management, provide activities for the development of processes for all staff, ensuring the welfare of staff and students, and staff and student welfare. The fourth, resources and administrators, including identify the resources needed and allocate these resources according to need, manage school funds, provides administrative support, manage and maintain buildings and other facilities, and maintaining buildings and other facilities. $^{13}$

\section{Factors to Consider}

There are several things; which should be a serious concern in organizing an EPP (English Proficiency Program) program. ${ }^{14}$ Those aspects are school obligations, government policies and priorities, the role of parents and society, the role of professionalism, managerial and organizing EPP (English Proficiency Program), and professional development

The implementation of school-based management needs to be accompanied by monitoring obligations and determining relatively high responsibilities in this case the school is given autonomy which automatically has the obligation to implement government policies and meet the expectations of the school community. School-

\footnotetext{
${ }^{13} \mathrm{Ibid}, 35$

${ }^{14}$ Wayan Koster, "Restrukturisasi Penyelenggaraan Pendidikan", Jurnal Pendidikan Dan Kebudayaan, No 026, 2000
} 
based management provides the widest possible opportunity for school principals, teachers and education managers to carry out the obligations given by the government and meet the expectations of the school community.

Government policies must look at what priorities to be achieved so that schools in implementing government policies are not wrong. For this reason, the government must make general guidelines regarding the implementation of SBM. So that the results of SBM can be evaluated properly and can be implemented effectively.

In SBM it requires the active role of parents and the community so that they feel they own the school and are also responsible for the success of the school. Through the school council parents and the community can participate in making various decisions. So that there is no overlap in school management between parents, schools and the community. So the government must make guidelines for forms of community participation.

School-based management demands many changes in behavior to teacher and administrative schools which must have a professional and management nature. Principals as top leaders are required to have good skills in order to be able to direct all policies of the school itself. For school needs the principal must, have the ability to collaborate with teachers and the surrounding community, broad insight about the theory of education and learning, to analyze the present situation, based on what should be and be able to predict future events based on the present situation, and able to take advantage of various opportunities, make challenges as opportunities, and conceptualize new directions for change..$^{15}$

In implementing SBM the government must open as early as possible professional development training. This professional development center functions as a service provider for education staff training for SBM. Schools and the community should be involved directly by involving themselves in discussions about SBM.

\section{School Based Management Implementation}

Implementation Strategy of SBM

In order for the implementation of school-based management to take place properly, it must also be supported by professional teaching staff. Adequate school

${ }^{15}$ M. Jihad Helmi AF., Peningkatan Mutu Tenaga Pendidikan, Akademika, 2002 
institutions, adequate facilities and infrastructure that are not less important are funding problems and the active role of parents. But due to the crisis experienced by our nation has brought more or less harm to the world of education. Seen from the students who continue to decline from year to year, the active role of the community also decreases because they prioritize their mind and energy and money to meet their daily needs.

As a new paradigm, in addition to maintaining the condition of the school, the implementation of the EPP (English Proficiency Program) program also requires proper phasing for the stages carried out, namely: promoting the EPP concept to all school members, conduct an analysis of the target situation (output), formulate goals, conduct a SWOT analysis, develop a quality improvement plan, conduct an evaluation of the implementation, and formulating new quality objectives. ${ }^{16}$

In relation to the implementation phase of the SBM, Broadly speaking, Fattah quoted by Mulyasa divided it into three stages: socialization, plotting and dissemination ${ }^{17}$. There are several points known as The EPP (English Proficiency Program) implementation tool, those are, readiness of human resources related to the implementation of SBM, school and regional categories, regulations / policies and guidelines, school plans, funding plan, internal monitoring and evaluation, external monitoring and evaluation, and final report. ${ }^{18}$

To be able to implement school-based quality improvement management, schools must carry out the following stages of activity: preparation of a more representative accurate, valid and systematic database and school profile concerning all aspects, conduct self-evaluation, and after self-evaluation and analysis, based on the analysis the school begins to arrange, identify school needs and formulate a vision, mission and goals as well as things that can support the teaching and learning process

Departing from the vision, mission and quality improvement objectives, the school together with the community plans and prepares long-term and short-term (annual) programs. This school program planning must include indicators / quality targets to be achieved in the year as a process of improvement quality of education

\footnotetext{
${ }^{16} \mathrm{Ahmad}$ D. Marimba, Pengantar Filsafat Pendidikan Islam, (Bandung: PT Al-Ma'arif, 1989), 19

${ }^{17}$ Hasan Langgulung, Asas-Asas Pendidikan Islam, (Jakarta: Pustaka Al-Husna, 1987), 4

${ }^{18} \mathrm{Ibid}, 32$
} 
Priorities are often not attainable within one year of the school program, therefore schools must develop long-term planning and development strategies through identification of key policies and priorities.

Carry out monitoring and evaluation to be able to ensure whether the planned program can be implemented in accordance with the objectives, whether the objectives have been achieved and the extent of their achievement. ${ }^{19}$ Because our focus is on the quality of students, monitoring and evaluation activities must meet the needs to meet the students' learning processes and outcomes.

\section{Analysis of Education Quality (English Language Ability)}

\section{Definition of Education}

Etymologically the meaning of education is the same as 'education' in English which comes from the Latin 'educere' which means to enter something. Intended to enter something of knowledge to someone (students). Whereas in the Arabic context, there are several terms that are usually used in the sense of education, including ta'lim, tarbiyah, and ta'dhib.

Whereas in terminology, among others, according to Ahmad D. Marimba gives the definition of education as follows: "Education is the guidance or leadership consciously by the educator on the physical and spiritual development before the educated towards the formation of the main personality". ${ }^{20}$ while George F. Kneller provides the following educational limits: "Education is the process of self realization in which the self realizies and develops all its potential". It means: "Education is a process of self-awareness or self-awareness in realizing itself and developing all its potential".

From this understanding, the writer can draw a conclusion that education is an intentional activity, providing physical and spiritual guidance from the educator to the educated person by instilling noble morals, moral, mental and physical training, so as to produce changes that are manifested in real life. While the quality or quality of education is "a comprehensive description and characteristics of the goods / services that show their ability to satisfy the specified or implied needs". In general, quality can / can mean the degree (level) of excellence of a product (work)

${ }^{19}$ Ahmad D. Marimba, Pengantar Filsafat Pendidikan Islam, (Bandung: PT Al-Ma'arif, 1989), 27

${ }^{20}$ George F. Kneller, Logic And Language Of Education, New York: Jhon Willey And Sons, Inc, 1966), 14-15. 
in the form of goods or services, both tangible (tangible or tangible) or intangible (intangible or intangible). "In the context of education understanding of the quality of education refers to the process and results of education". In the process of quality education also involved a variety of inputs such as teaching materials, methodologies, infrastructure, resources, and the creation of a conducive atmosphere

\section{Educational Process}

The process of education is the change of "something" to "something else". Whereas what affects the process is input, and the output of the process is output. In the EPP education system the intended process are decision making process, institutional management process, program management process, and the process of teaching and learning.

Therefore the process of organizing the EPP program is an integrated part of the school's function and task unit as an education unit. These school functions include the following: preparing Students to get a job, provide basic skills, and provide general knowledge.

For students who have graduated in pursuing their education, it is expected to be able to get even open certain jobs that can help them exist in their own lives. Therefore it is ideal that the higher the level of education is expected to be able to have a better job and success.

Schools are able to provide basic skills (lift-skills) that can deliver it at the desired level of success in life. One of the skills and life skills needed in the current era is the ability to speak English as an international language of communication to bridge the acculturation of Indonesian culture as part of the world culture that will be integrated in a unit of living together without limits, including the work world.

The intended general knowledge is a number of basic knowledge, especially related to real life in the current era, such as IT skills, language, and other exact knowledge. This knowledge will be very useful for the development and improvement of the quality of life of everyone, so that the school is the gate of selfimprovement and civilization. ${ }^{21}$

\section{Institutional Management} Putra, 2005)

${ }^{21}$ Dawam, Ainurrafiq, et.al., Manajemen Madrasah Berbasis Pesantren, (Yogyakarta: Listafariska 
Schools as educational institutions must be professionally managed so that they become "learning schools" that are able to guarantee their survival and development. Therefore, to become a learning school, schools must be able to empowering HR as optimal as possible, facilitating school residents to continue learning and relearn, encourage independence (autonomy) of each citizen, give responsibilities to its citizens, encourage every citizen to be held accountable (accountability) for his work, encourage the existence of a compact and intelligent teamwork and shared of values for each of its citizens, respond quickly to the market (customer), inviting citizens to make their schools customer service, inviting its citizens to enjoy and be ready for change, encourage citizens to think systems, both in thinking, managing and analyzing their schools, involve citizens for a commitment to "quality excellence", inviting its citizens to make improvements continuously, and involve citizens in total school management. ${ }^{22}$

In an education organization, empowerment of human resources (HR), educators and education personnel becomes very important. Because an education will produce quality education if accompanied by continuous efforts to improve the quality of educators. At other times that in a school there will be great students because there are many great teachers in it. Because basically every human being is an intelligent human and the best of creation that can always improve its abilities. In accordance with the word of Allah SWT in the Qur'an at-Tin: 4-6

"We have certainly created man in the best of stature; Then We return him to the lowest of the low, Except for those who believe and do righteous deeds, for they will have a reward uninterrupted. (QS: At-Tiin 4-6)"

"Curriculum management and teaching programs include planning, implementation and assessment activities". ${ }^{23}$ Program management is the coordination and harmonization of school programs, which include: planning, developing, and evaluating school programs, curriculum development, development of PBM, HR Management, student services, facility management, financial management, improvements to the program, and fostering relationships between schools and the community. ${ }^{24}$

${ }^{22}$ M. Jihad Helmi AF., "Peningkatan Mutu Tenaga Pendidikan”, Akademika, 2002

${ }^{23}$ Suyantodan Abbas, Wajah Dinamika Pendidikan Anak Bangsa, (Yogyakarta: Adicita, 2001) 79

${ }^{24}$ Ahmad D. Marimba, Pengantar Filsafat Pendidikan Islam, (Bandung: PT Al-Ma'arif, 1989) 45 


\section{Learning process}

Teaching and learning process is a series of teaching and learning activities to achieve a predetermined teaching goal. No matter how perfect the goal formulation is, if the way to achieve that goal will not be managed properly, the achievement of that goal will not succeed perfectly. In relation to the above, sometimes a teacher is faced with students who have learning difficulties. Because a teacher must master the skills in the learning process in the classroom.

As for some important things that can be used as a basic reference for improving teaching and learning, namely: purpose, material, method, and tool.

The purpose of education and teaching must be understood and understood correctly because the causes and goals that will later become a picture, target and direction for the actions of teachers in carrying out their functions.

Law No. 20 of 2003 article 1 paragraph 1 explains that education is a conscious and planned effort to create an atmosphere of learning and learning process so that students actively develop their personal potential to have religious spiritual strength, self-control, personality, intelligence, noble character and skills needed by themselves, society, nation and state. ${ }^{25}$ Meanwhile according to Law No. 4 of 1950 concerning education and teaching Chapter II article 3 states that: "The aim of education and teaching is to form capable human beings and citizens who are democratic and responsible for the welfare of the community and the motherland." 26 In addition, objectives also function as criteria in the selection and determination of both the material, tools and methods and evaluations that will be used in teaching.

The material is material that will be delivered in teaching and learning activities. According to Nasution, that the lesson there are three sources namely society and culture, children with their interests and needs, as well as knowledge that has been collected by humans as a result of their experiences and has been systematically compiled by scientists in a number of scientific disciplines. ${ }^{27}$

However, even though the material sources are known, choosing the material itself remains complex. For this reason, according to Hilda Taba as quoted by

${ }^{25}$ Depniknas, Undang-Undang Nomor 20 Tahun 2003 Tentang Sistem Pendidikan Nasional, (Jakarta: Depdiknas, 2003)

${ }^{26}$ Zuhairini et. al., Metodik Khusus Pendidikan Agama, (Malang: Biro Alamiah FT IAIN Sunan Ampel, 1991), 178

${ }^{27} \mathrm{Ibid}, 43$ 
Nasution, the material criteria must meet the validity of knowledge, relevance, balance, diversity of goals, student abilities, and students' needs and interests.

The method is a way whose function is no more as a tool to convey knowledge, skills, and attitudes to students. According to Winarno S. there are 10 teaching methods, namely: lecture method, the method of drill / drill ready, question and answer method, methods of discussion / deliberation, demonstration method, recitation method, the method of field trip, group work methods, team system method, and socio drama method. ${ }^{28}$

In reality, not all methods are used in one meeting. The number of methods according to Winarno Surahmad is caused because it is influenced by many factors including the objectives are various types and functions, students whose various levels of maturity, situations with various conditions, facilities of various quality and quantity, and personal teacher and different professional abilities ${ }^{29}$

The important thing that teachers must pay attention to in using methods is the limits of the good and weakness of the methods they use to be able to formulate conclusions about the results of the evaluation of their efforts.

The tool is a teaching tool whose function is to help achieve a goal. In addition, the tool also helps establish harmonious communication between teachers and students in the teaching and learning process. Ahmad D. Marimba divides the characteristics of educational tools according to the level of development and difficulties that will be received by children (students), namely: tools that provide equipment in the form of conversation, action and knowledge, memorization, these tools can be called tools for habituation, tools for giving understanding, making attitudes, interests and ways of thinking, and tools that lead to inner silence of trust and surrender completely to Him.

Evaluation

Evaluation, which is an integral part of the teaching and learning process, must be carried out continuously in order to achieve educational goals. This evaluation is not only done by the teacher to their students, but also can be done by students to the teacher and the evaluation by the teacher to himself. This evaluation

${ }^{28}$ Winarno,Metodologi Pengajaran Nasional,(Bandung: Jemmars, 1980), 106

${ }^{29} \mathrm{Ibid}, 112$ 
will help to know the extent to which teaching and learning outcomes have been achieved.

In general, learning achievement that can be achieved by a school in organizing educational processes (student achievement) can be divided into two, namely in the academic and non-academic fields. ${ }^{30}$ Academic ability can be seen in the achievement of test results such as UH, PTS, PAS and UNBK while the results that are non-academic are a kind of specific skills or expertise that can be mastered by students while attending the learning and education process in schools such as sports skills, foreign language skills, art skills and so on.

The implementation of the EPP program at SMP Muhammadiyah 2 Taman was arguably successful because since it was first pioneered and organized the program continued to experience changes towards a better direction, regarding the implementation curriculum, the quality of teaching staff, as well as learning methodologies and learning facilities that continue to be improved. So that students speak English has become a life skill that is integrated with the mastery of other knowledge. This fact can be seen by the increasing learning achievement of students who are active in EPP activities in the form of an increase in report cards and UN scores for grade 9 students. On the other hand can also be observed in the language skills of students for certain communities especially those active in the EPP program.

\section{Conclusions}

From the description above, it can be concluded that the strengthening of EPP (English Proficiency Program) learning in schools

1. Is a school-based management strategy that, if implemented well, will produce good school graduates.

2. EPP (English Proficiency Program) activities can improve students' academic and non-academic abilities.

\section{References}

A, Iskandar and Yufridawati, "Pengembangan Pola Kerja Harmonis dan Sinergis Antara Guru, Kepala Koster, Restrukturisasi Penyelenggaraan Pendidikan, Jurnal Pendidikan Dan Kebudayaan, No 026, 2000

${ }^{30}$ Sulistyani, Ambar Teguh and Rosidah, 2009, Manajemen Sumber Daya Manusia: Konsep, Teori dan Pengembangan dalam Konteks Organisasi Publik, $2^{\text {nd }}$ Ed.,(Yogyakarta: Graha Ilmu, 2009)18 
Bachtiar, W. Metodologi Penelitian Ilmu Dakwah. $1^{\text {st }}$ Ed. Jakarta: Wacana Ilmu Logos, 1997.

Barnawi and Arifin, M., Kinerja Guru Profesional, Jogjakarta: Ar-Ruzz Media, 2012.

Dawam, Ainurrafiq, et.al., Manajemen Madrasah Berbasis Pesantren, $2^{\text {nd }}$ Ed. Yogyakarta: Listafariska Putra, 2005.

Depdiknas. Kepemimpinan Kepala Sekolah Dalam Meningkatkan Sumber Daya Manusia Di Sekolah Dasar, Jakarta. 2007.

Gatot, S. and E, Martono, Ilmu dan Seni Kepemimpinan, Bandung :Pustaka Reka Cipta, 2014

Helmi AF., Jihad, "Peningkatan Mutu Tenaga Pendidikan", in Akademika Magazine, Gunungesagi Offset, no. 59, 25 April 2002,

Kneller, George F., Logic and Language of Education, New York: Jhon Willey And Sons, Inc, 1966

Koster, Wayan, "Restrukturisasi Penyelenggaraan Pendidikan", Jurnal Pendidikan Dan Kebudayaan, No 026, 2000

Langgulung, Hasan, Asas-Asas Pendidikan Islam, Jakarta: Pustaka Al-Husna, 1987

Marimba, Ahmad D., Pengantar Filsafat Pendidikan Islam, Bandung: PT Al-Ma'arif, 1989.

Muhadjir, N. Metodologi Penelitian Kualitatif. $4^{\text {th }}$ Ed., Yogyakarta: Rake Sarasin, 2000.

Mulyasa, E., Menjadi Kepala Sekolah Profesional, Bandung: PT Remaja Rosdakarya, 2006.

Rahmat and Suharto, Edi, “Konsep Manajemen Berbasis Sekolah”, 25 Juni 2001,

Sugiyono, Metode Penelitian Pendidikan, PendekatanKuantitatif, Kualitatif dan RandD, Bandung: Alfabeta, 2011

Sulistyani, Teguh, Ambar and Rosidah, Manajemen Sumber Daya Manusia: Konsep, Teori dan Pengembangan dalam Konteks Organisasi Publik, $2^{\text {nd }}$ Ed., Graha Ilmu, Yogyakarta, 2009.

Suyanto and Abbas, Wajah Dinamika Pendidikan Anak Bangsa, Yogyakarta: Adicita, 2001

Taufiqurrahman, “Manajemen Berbasis Sekolah” Jurnal Studi Keislaman, 2002

Wahyosumidjo, Kepemimpinan Kepala Sekolah, Jakarta: Grafindo Persada, 2002

Winarno, Metodologi Pengajaran Nasional, Bandung: Jemmars, 1980

Zuhairini et.al., Metodik Khusus Pendidikan Agama, Malang: Biro Alamiah FT IAIN Sunan Ampel, 1991 